\title{
Physical and Chemical Characteristics of Teak (Tectona Grandis) Leaves as Food Packaging Material
}

\author{
Swastika Dewi ${ }^{* *}$, Supriyadi ${ }^{2}$, Umar Santoso ${ }^{1}$ \\ ${ }^{1}$ Department of Food Science and Technology, Faculty of Agricultural Technology, Universitas Gadjah Mada, J1. Flora No. 1 \\ Bulaksumur, Yogyakarta, 55281 \\ ${ }^{2}$ Department of Plantation Technology, Faculty of Agricultural Technology, Universitas Gadjah Mada, Jl. Flora No. 1 Bulaksumur, \\ Yogyakarta, 55281 \\ ${ }^{*}$ Correspondence author: swastika@mail.ugm.ac.id
}

\begin{abstract}
Teak (Tectona grandis) leaves is commonly used as the packaging material of traditional food in Indonesia. This study aimed to determine the physical and chemical characteristics of teak leaves with various maturation stages to obtain information about the potency of teak leaves as active packaging material. The physical characteristics analysis included leaf color, thickness, and tensile strength, while chemical characteristics were moisture, fat content, fatty acid, and volatile profile. The results showed that the color, thickness, tensile strength, moisture, and fat content, were light green, $0.306 \pm 0.024 \mathrm{~mm}, 0.22 \pm 0.114 \mathrm{MPa}, 74.93 \%$, and $2.52 \%$ respectively for young teak leaves; while the mature has darker green, $0.388 \pm 0.001 \mathrm{~mm}, 0.36 \pm 0.163 \mathrm{MPa}, 73.05 \%$, and $2.54 \%$ respectively. The fatty acid profiles showed that young teak leaves contained 5 types of fatty acids, dominated by lignoceric acid; while mature teak leaves contained 9 types of fatty acids dominated by tricosanoic acid. The volatile components of young teak leaves e.g. acid and ester compounds, while the mature was dominated by acid and ether compounds. From the results, it is suggested that the use of teak leaves as active food packaging material can be scientifically justified.
\end{abstract}

Keywords: teak leaves, physical and chemical characteristic, active food packaging material

\section{INTRODUCTION}

Teak (Tectona grandis) leaves commonly used as a food packaging material by the people in Indonesia, since a long time ago. The reason for choosing this leaves for packaging materials on traditional foods has not been supported by scientific studies. Leaves are known as eco-friendly food packaging material (Casey, 2015). But now, the recent lifestyle change the traditional packaging become the modern one, like paper cup, plastics, and so on (Noviadji, 2014). As we know, modern packaging materials are not eco-friendly, so it is necessary to maintain the traditional packaging become a natural packaging that suitable for use.

In Indonesia, teak leaves were used as the packaging of jamblang rice, fresh meat and fish, and tempe, especially in Java region. Teak leaves along with six other types of leaves, namely banana leaves, mussels, coconut leaves, palm leaves, guava leaves, and hanjuang leaves are commonly used as packaging for traditional foods (Maflahah, 2012). The basis for selecting natural raw materials from these leaves were easy to obtain, cheap, can be a source of income for rural people, environmental friendly, give a characteristic to the product, contribute distinctive aroma and flavor to the product, and safe for consumption or non-contaminating products (Natadjaja and Yuwono, 2017). However, the leaves itself as food packaging materials, especially in the aspect of the most optimum age of maturation of teak leaves as food packaging has not been studied yet.

In the present study, the physical and chemical characteristics of teak leaves were examined to obtain information about the potential of the leaves to be used as food packaging material. The scientific consideration for selecting the leaves as packaging materials is due to their physical and chemical characteristics. The analysis for physical characteristics including color, thickness, and tensile strength. For chemical characteristics including moisture, fat content, fatty acids profile analysis, and volatile profile analysis of teak leaves. This research is expected to be the basic science for the development of leaves as ecofriendly packaging materials. The purpose of this study is to examine the physical and chemical characteristics of teak leaves with various age of maturation as active food packaging material.

\section{MATERIALS AND METHODS}

\section{Materials}

The leaves were taken from the teak plant grown at Maguwoharjo and Umbulharjo, Yogyakarta Special Region. The teak leaves used were young teak leaves (shoots 1 and 2) light green in color, and mature teak leaves (shoots 3,4, and 5) dark green in color. The selection of the leaves based on the usage of the leaves by the people in the local region. Chemicals used were dichloromethane, pentane, anhydrous $\mathrm{Na}_{2} \mathrm{SO}_{4}$, liquid nitrogen, sodium carbonate, Petroleum Ether (PE), sodium methanolic, and boron trifluoride methanoate.

\section{Sample Preparation}

For preparation of the leaves, they were picked, sorted and trimmed for good quality parts of the leaves. The leaves were used as the sample for physical and chemical analysis. After sample preparation, the physical characteristics analysis included color, thickness, and tensile strength were performed, followed by chemical characteristics analysis included water content, fat content, fatty acid profile, and volatile profile.

\section{Leaf color}

The color testing was carried out with a chromameter 
CHROMAMETER CR 400 Series (Konica Minolta Optics, Inc., America) by measuring Lightness (L), appearance (a), and blueness (b) (Tsai and Li, 2021).

\section{Tensile strength}

Tensile strength testing for tensile strength value (TS) was carried out using Universal Testing Machine/UTM merk ZWICK/ZO5). The leaves have been cut uniformly according to the mold and then clamped and pulled until the leaves were cut (Guo et al., 2014).

\section{Leaf thickness}

Leaf thickness testing was done using a digital micrometer made by KRISBOW ${ }^{\circledR}$. Leaves were measured at the end, the middle and the base of the leaf, then drew the average number (White and Montes-R, 2005).

\section{Moisture content}

Moisture was determined by the oven-thermogravimetric method. An empty bottle or porcelain disk was weighed, one gram of wet leaves sample inserted into the bottle and then dried to a constant weight at $102-105^{\circ} \mathrm{C}$ for $5-6 \mathrm{~h}$ (AOAC, 2005).

Moisture content $=\frac{(B-A)}{(B-C)} \times 100$

Note: $\mathrm{A}=$ dry weight of cup $(\mathrm{g})$

$\mathrm{B}=$ dry weight of cup and initial sample $(\mathrm{g})$

$\mathrm{C}=$ dry weight of cup and final sample $(\mathrm{g})$

\section{Fat content}

Fat content was analyzed by the Soxhlet extraction method (AOAC, 2005). Empty soxhlet flask (for Soxhlet extraction) was weighed in advance. One gram of dried powder of the leaves sample was weighed and put in the filter paper sleeve and closed. Then, the sleeve was inserted into the Soxhlet tube extractor chamber and doused with 15 $\mathrm{ml} \mathrm{PE}$ solvent, then heated using an electric heater for 4-5 h. Afterward, the extraction flask was dried in oven $\left(105^{\circ} \mathrm{C}\right)$ until the weight was constant.

Calculation of crude fat content:

$\%$ Fat on dry weight basis $=$

( $g$ of fat in sample/g of dried sample) x 100

\section{Fatty acid profile}

Fatty acids profile was carried out by Gas Chromatograph (GC) of Agilent completed with Flame Ionized Detector (FID). The condition of Gas Chromatograph was used Gas DB-23 column, $30 \mathrm{~m}$ length, $0.25 \mathrm{~mm}$ inner diameter, $0.25 \mu \mathrm{m}$ particle layer diameter, and nitrogen as the carrier gas. The volume of sample injected was $1 \mu \mathrm{L}$, injector temperature $100^{\circ} \mathrm{C}$ was held for $5 \mathrm{~min}$, the oven temperature was increased to $275^{\circ} \mathrm{C}$ at $4^{\circ} \mathrm{C} / \mathrm{min}$ rate, and held for $10 \mathrm{~min}$. The heating temperature system was isothermal with initial temperature of $290^{\circ} \mathrm{C}$, then was held for $15 \mathrm{~min}$. The obtained leaf samples fat was methylated, $0.5 \mathrm{ml}$ of fat sample added by $1.5 \mathrm{ml}$ of methanolic sodium solution, heated at $80^{\circ} \mathrm{C}$ for $20 \mathrm{~min}$ while shaken, then the samples were cooled after heating was completed. Two ml of methanoate boron trifluoride was put into the sample and reheated at $80^{\circ} \mathrm{C}$ for $20 \mathrm{~min}$, and cooled. After that, extraction was carried out by adding $1 \mathrm{ml}$ of hexane and 1 $\mathrm{ml}$ of saturated $\mathrm{NaCl}$. The top of layer formed was taken and put into the Eppendorf tube, the methylated sample was injected into the GC and detected by the FID detector $\left(285^{\circ} \mathrm{C}\right.$ detector temperature). This test used the standard mix methyl ester (FAME) Supelco brand which was the standard containing the mixture several types of fatty acids (C4-C24). The way to identify the leaves fatty acid profile was to compare the retention time at the peak of the fatty acid chromatogram sample with the retention time of the chromatogram peak on the external standard that has known composition and concentration, then compared the peak area of each sample fatty acid to the standard so that the concentration was known (Socaci et al., 2009).

\section{Screening of volatile compounds}

Teak leaves were reduced in size for $\pm 2 \mathrm{~cm} \times 2 \mathrm{~cm}$ and weighed for $30 \mathrm{~g}$. Nitrogen (liquid) was added to the leaves and then the milling was done until the leaves became powder. This was followed by the addition of pentane:dichloromethane $(2: 1,200 \mathrm{~mL}: 100 \mathrm{~mL})$ to that powder and then mixed (190 rpm) with shaker. After that, the mixture was macerated overnight at $4^{\circ} \mathrm{C}$. In the next step, the leaves extract was separated from the leaf residue and added with $\mathrm{Na}_{2} \mathrm{SO}_{4}$ anhydrous to remove the water. After filtration through Whatman filter paper (no. 42), residual solvent was carefully concentrated to a small volume (about $5 \mathrm{~mL}$ ), with a rotary evaporator. The concentrated extract (1-2 $\mu \mathrm{L})$ in pentane:dichloromethane $(1: 2 \mathrm{~b} / \mathrm{v})$ was analyzed by GC-MS for the detection of chemical components. Testing of volatile compounds was carried out using Agilent GC-MS, 30m DB-WAX column, $0.25 \mathrm{~mm}$ diameter, and $0.25 \mu \mathrm{m}$ diameter stationary particle layer diameter, helium carrier gas with flow rate of $0.8 \mathrm{ml} / \mathrm{min}$, sample volume injected. $0.5 \mu \mathrm{L}$ with a $100: 1$ split ratio and $250^{\circ} \mathrm{C}$ injector temperature, the temperature system used was isothermal at an oven temperature of $45^{\circ} \mathrm{C}$ and then increased to $250^{\circ} \mathrm{C}$ at a rate of $4^{\circ} \mathrm{C} / \mathrm{min}$ held for $5 \mathrm{~min}$. The type of volatile compound was determined by comparing the mass spectrum of the sample analyte with the mass spectrum in the pre-programmed database on GCMS (Kuo et al., 2006).

The database of National Institute of Standard and Technology (NIST) was used to interpretate the mass spectrum of GC-MS. Refer to (Muthulakshmi et al., 2012) the mass spectrum of the unknown component was compared with the spectrum of the known component stored in the NIST library. The name, molecular weight and structure of the components of the test materials were ascertained. The percentage calculation of volatile was done by calculating the peak area from the readable GCMS component graph, then comparing it with the total area of the peak component as a whole.

\section{Statistical analysis}

The statistical analysis that conducted for this research was univariate (Two Way) ANOVA with SPSS 16. The post hoc analysis was conducted by Duncan test. 


\section{RESULTS AND DISCUSSIONS}

\section{Color}

The mature teak leaves had a rather dark green color, whereas young teak leaves had a light green color. In Table 1 showed that lower $\mathrm{L}$ value indicates the darker color, while the higher $\mathrm{L}$ value indicated the brighter color. A higher value of " $\mathrm{A}$ " color parameter indicated red color while lower value indicated green color. B color parameter value indicated yellow color in higher value and blue color in lower value.

Table 1. Color of Teak Leaves

\begin{tabular}{ccc}
\hline \multirow{2}{*}{$\begin{array}{c}\text { Color } \\
\text { Parameter }\end{array}$} & \multicolumn{2}{c}{ Teak Leaves } \\
\cline { 2 - 3 } & \multicolumn{1}{c}{ Young } & \multicolumn{1}{c}{ Mature } \\
\hline L & $31.89 \pm 4.57^{\mathrm{a}}$ & $25.18 \pm 3.07^{\mathrm{b}}$ \\
A & $-8.93 \pm 1.00^{\mathrm{a}}$ & $1.08 \pm 1.10^{\mathrm{b}}$ \\
B & $16.04 \pm 2.79^{\mathrm{a}}$ & $9.58 \pm 4.66^{\mathrm{b}}$ \\
\hline
\end{tabular}

a-b Different superscript notations show significantly different (in the same row) $(\mathrm{p} \leq 0.05)$
In the Special Region of Yogyakarta, Indonesia, the teak plants were grown with 5-6 parts of leaves at each branch. According to the use of the leaves by the people in the local region it was used for food packaging materials, in this study, the selected young teak leaves were shoots 1 and 2, light green in color; and mature teak leaves (shoots 3,4 , and 5) dark green in color. The most useful for food packaging material of teak leaves is the mature leaves but the young leaves were suspected to have higher content of bioactive compounds. So, this study was conducted to use two categories of that leaves. From the color analysis, the young leaves had brighter green color than the mature. The differences in the color of young and mature leaves may occur due to differences in the chlorophyll content of young and mature leaves, that was the possibility of mature leaves containing more chlorophyll for the preparation of the photosynthesis process (Ibanez et al., 2008). However, it is necessary to further investigate the biosynthetic process in leaves to conclude this.

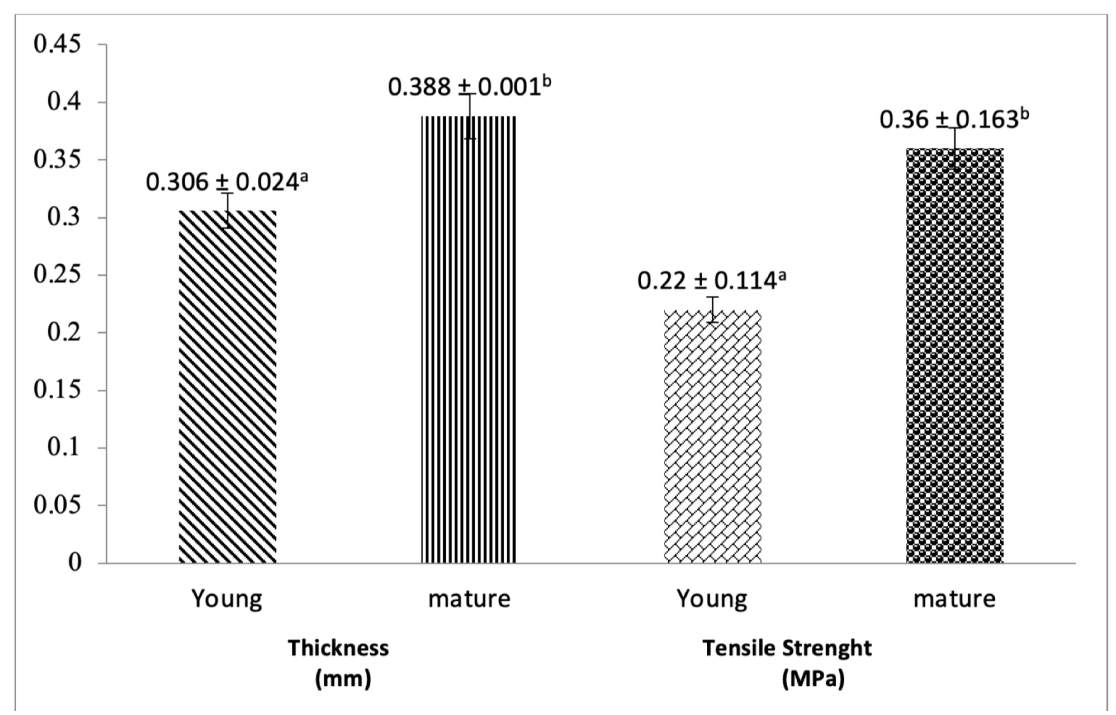

Figure 1. The thickness and Tensile Strength of Teak leaves

$a-b$ Different superscript notations show significantly different (in the same row) $(p \leq 0.05)$

\section{Thickness and Tensile Strength}

Based on Figure 1, the thickness of mature teak leaves was $0.388 \pm 0.001 \mathrm{~mm}$ a little higher than young teak leaves $(0.306 \pm 0.024 \mathrm{~mm})$. There were no significant differences between the mature and young teak leaves because of the proximity of the shoot selected. The tensile strength of the young teak leaves was $0.22 \pm 0.114 \mathrm{Mpa}$ and $0.36 \pm 0.163$ Mpa for mature teak leaves. From the result above, it can be seen that the process of growth and development of leaves affects the higher value of the tensile strength.

The young leaves had a lower value of thickness than the mature. The differences between the thickness of leaves caused by the microstructure of the leaves. It could be influenced by the rate of respiration, photosynthesis rate, accumulation of water, and accumulation of glucose from both leaves, which higher at the mature leaves (Nayeem and
Karvekar, 2010). The process of growth and development of leaves also could affect the higher value of the tensile strength. So, the tensile strength of the young leaves is lower than the mature leaves.

\section{Moisture and Fat Content}

The moisture of mature teak leaves was 73.05 a little lower than young teak leaves $(74.93 \%)$. There were no significant differences between the mature and young leaves because of the proximity of the shoot selected $(\mathrm{p}>0.05)$. Mature teak leaves had $2.54 \%$ of fat content, and for the young teak leaves was $2.52 \%$. There were no significant differences between the mature and young leaves $(p>0.05)$. This result was also because the proximity of the shoot selected. 


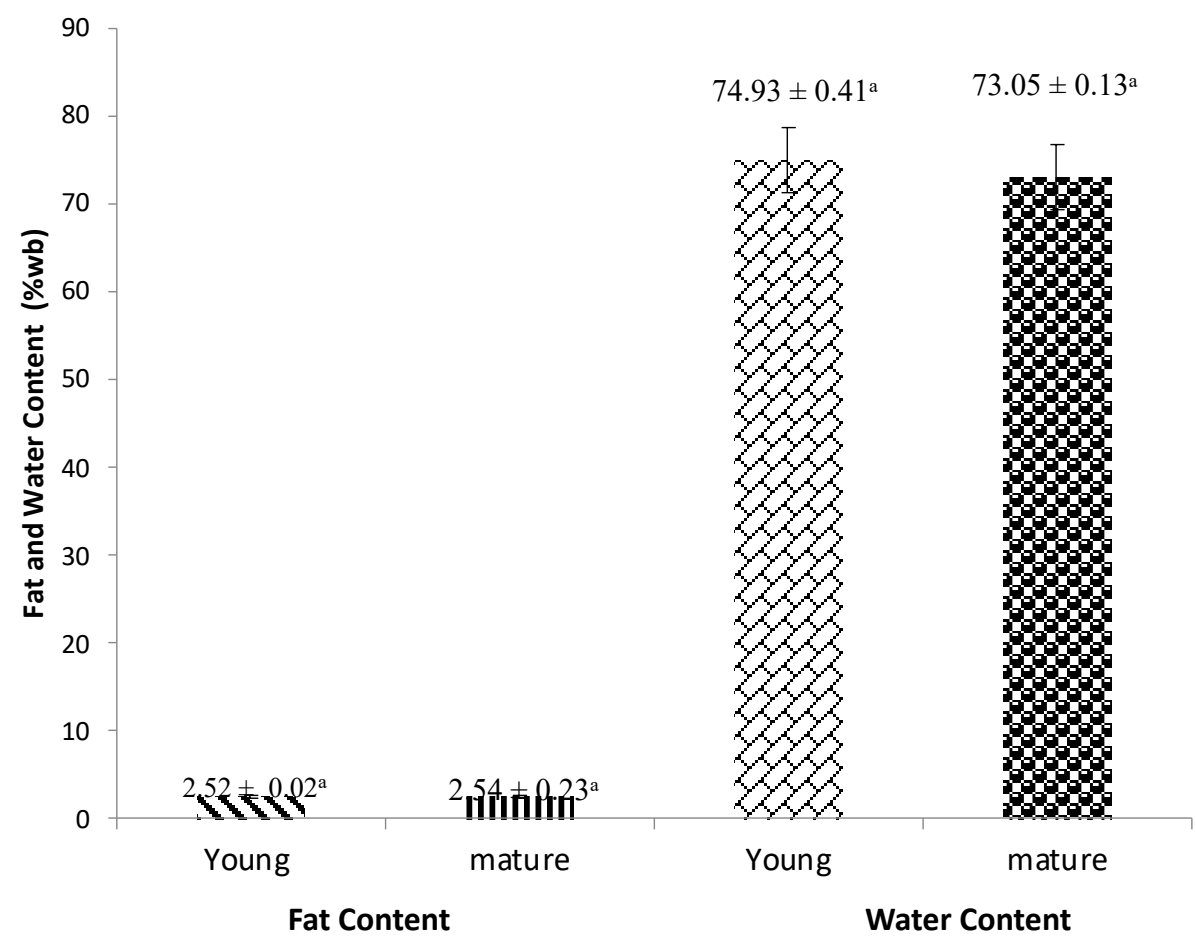

Figure 3. Moisture and Fat Content of Teak leaves a-b Different superscript notations show significantly different (in the same row) ( $\mathrm{p} \leq 0.05)$

According to Abqoriyah and Suwignyo (2015), the younger leaves had higher composition of water content because when a plant getting older, the crude fiber content will increase. This explained the reason why the water content decreased. In the book of plant physiology by Salisbury and Ross (1995), the age of plants can affect the water content in plant material, the level of dry matter increased with the age of the plant. The fat content of young and mature teak leaves was not significantly different. Abqoriyah et al. (2015) also reported that the younger leaves had lower composition of fat content. This was in accordance with the study of Koten (2013) that in older plant had higher value of fat content. Fat is part of the protoplasts, increase plant growth phase from vegetative to generative, causing protoplast in the vegetative part of the plant to be reduced, thus impacting fat content.

\section{Fatty Acid Profile}

The fatty acid profiles of teak leaves (Table 2) showed that young teak leaves contained 5 types of fatty acids, dominated by lignoceric acid, then eicosapentanoic acid, linoleic acid, tricosanoic acid, and cis-9-oleic acid. The mature leaves contained 9 types of fatty acids dominated by tricosanoic acid, then eicosatrienoic acid, linolenic acid, erucic acid, linoleic acid, eicosapentanoic acid, cis9-oleic acid, stearic acid, and lignoceric acid. The standard deviation of the component was not calculated because of the component just tested once then written in the table.
Table 2. Fatty Acid Profile of Teak Leaves

\begin{tabular}{lcc}
\hline \multirow{2}{*}{\multicolumn{1}{c}{ Fatty Acid }} & \multicolumn{2}{c}{ Relative area (\%) } \\
\cline { 2 - 3 } & \multicolumn{2}{c}{ Teak Leaves } \\
\cline { 2 - 3 } & Young & Mature \\
\hline Cis-9-Oleic Acid & $14.07 \pm 9.9$ & $10.23 \pm 7.23$ \\
Stearic Acid & - & $9.55 \pm 6.75$ \\
Linoleic Acid & $17.14 \pm 12.12$ & $12.37 \pm 8.75$ \\
Linolenic Acid & - & $17.36 \pm 12.27$ \\
Eicosatrienoic Acid & - & $18.95 \pm 4.67$ \\
Eicosapentanoic Acid & $23.04 \pm 2.86$ & $11.59 \pm 8.19$ \\
Erucic Acid & - & $15.42 \pm 4.62$ \\
Tricosanoic Acid & $15.64 \pm 3.06$ & $30.74 \pm 9.16$ \\
Lignoceric Acid & $45.66 \pm 1.97$ & $8.62 \pm 6.09$ \\
\hline
\end{tabular}

From the fatty acid profile result, the dominant fatty acid in young teak leaves was saturated fatty acid (SFA) while mature teak leaves was unsaturated fatty acid. The presence of more unsaturated fatty acids in mature teak leaves can be caused by the photosynthesis process that occurs. In the process of photosynthesis, free fatty acids are undesirable which can inhibit electron transport for energy production. The development of mature teak leaves shows the maturity of its secondary metabolite content, including the presence of unsaturated fatty acids. It is possible that free fatty acids have the potential to be present in higher amounts from leaves that have saturated fatty acids, which has not undergone further development. In other words, it is possible that there are more free fatty acids in young teak leaves (Zhang et al., 2010).

Lignoceric acid was present in abundant amount in young teak leaves but changed in mature teak leaves, this fatty acid present in the smallest amount after the development of the plant. The different stages of development of plants can 
affect the amount, type and quantity of the plant metabolite (Nayeem and Karvekar, 2010).

\section{Volatile Compounds}

Nowadays the study of the organic compounds from plants and its material, their composition and activities have increased. The GC-MS is the most ideal technique for qualitative and quantitative analysis of volatile and semi- volatile bioactive compounds (Grover and Patni, 2013) and is used in the present study. The results of GC-MS analysis of volatile compounds of teak leaves were shown in Table 3 , respectively. The extracts of teak leaves consisted of complex mixtures of various types of organic compounds. The identified compounds included esters, fatty acids, ethers, and their derivatives.

Table 3. Volatile Compounds of Teak Leaves

\begin{tabular}{llcc}
\hline \multicolumn{1}{c}{ Classification } & \multicolumn{1}{c}{ Volatile Compounds } & \multicolumn{2}{c}{ Peak Area (\%) } \\
\cline { 2 - 3 } & & $\begin{array}{c}\text { Young teak } \\
\text { leaves }\end{array}$ & $\begin{array}{c}\text { Mature teak } \\
\text { leaves }\end{array}$ \\
\hline Acid & cis-Vaccenic acid & 12.1 & 33.37 \\
Acid & Glycidyl palmitate & n.d. & 6.01 \\
Ester & 9-Octadecenoic acid (Z)-, hexyl ester & 0.21 & n.d. \\
Acid & Glycidyl oleate & n.d. & 14.77 \\
Acid & 9-Hexadecenoic acid & 0.85 & 2.4 \\
Steroid derivative & Ethyl iso-allocholate & 0.57 & 2.24 \\
Ester & trans-9-Octadecenoic acid, pentyl ester & 0.17 & 1.02 \\
Acid & Dodecanoic acid, 3-hydroxy- & n.d. \\
Ester & Oxiraneundecanoic acid, 3-pentyl-, methyl ester & 0.11 & 0.63 \\
Ester & 10-Heptadecen-8-ynoic acid, methyl ester, (E)- & 0.24 \\
Acid & Octadecanoic acid & n.d. \\
Ester & [1,1'-Bicyclopropyl]-2-octanoic acid, 2'-hexyl-, methyl ester & 0.61 & n.d. \\
Acid & 17-Octadecynoic acid & n.d. \\
Ester & 7-Methyl-Z-tetradecen-1-ol acetate & 4.73 \\
\hline
\end{tabular}

From the analysis of volatile profile, could be known that young teak leaves had nine component while mature teak leaves had ten component. The major phytoconstituents of young teak leaves extract were: cis-vaccenic acid (12.1\%), 7-methyl-Z-tetradecen-1-ol acetate (4.73\%), 9-hexadecenoic acid (0.85\%), [1,1'-Bicyclopropyl]-2octanoic acid, 2'-hexyl-, methyl ester $(0.61 \%)$, and ethyl iso-allocholate $(0.57 \%)$. The mature teak leaves contained cis-vaccenic acid (33.37\%), glycidyl oleate (14.77\%), glycidyl palmitate (6.01\%), 7-Methyl-Z-tetradecen-1ol acetate $(3.76 \%)$, and ethyl iso-allocholate $(2.24 \%)$ as the major component. The highest amount of volatile compound in young and mature teak leaves, cis-vaccenic acid also present in mango pulp lipids (Shibahara et al., 1986) and also in other fruit i.e. durian, apple, and lemon (Shibahara et al., 1987) whereas glycidyl oleate also found in vegetable oils (Haines et al., 2011).

The acid and ester groups dominated the volatile components of young teak leaves, while the acid groups dominated the volatile components of mature teak leaves. The results clearly showed that acids were the major compounds found in teak leaves extracts. Therefore, the study confirmed that the number of volatile compounds increased with maturity and thus young teak leaves showed a much lower diversity of compounds as compared to that mature teak leaves (Grover and Patni, 2013). This number of volatile compounds can affect to a presence of phenolic groups that can relate with an antioxidative capacity, such as the chlorogenic acid in the coffee beans (Cheong et al., 2013). In this case, according to literature, cis-vaccenic acid had a function to reduce fatty acid toxicity through storage lipid synthesis uses this fatty acid in baker's yeast deficient (Sec et al., 2015).

\section{CONCLUSION}

The physical characteristics of young teak leaves had brighter color, thickness and the tensile strength was not greater than the mature teak leaves. The analysis of fatty acid profiles indicate that teak leaves contained 9 types of fatty acids, the dominant ones was tricosanoic acid (30.74\%) in mature teak leaves and lignoceric acid $(45.66 \%)$ in young teak leaves. The acid and ester groups dominated the volatile components of young teak leaves, while the acid, such as cis-vaccenic acid and glycidyl oleate dominated the volatile components of mature teak leaves. From this study, it can be concluded that the use of teak leaves as food packaging material can be scientifically justified. Further research is needed to develop these leaves as potential active packaging materials.

\section{Acknowledgment}

The authors would like to thank the Ministry of Research Technology and Higher Education, Republic of Indonesia who provided financial support to this research, through Penelitian Dasar Unggulan Perguruan Tinggi (PDUPT) programme.

\section{REFERENCES}

Abqoriyah, R.U. and Suwignyo, B. 2015. Productivity of calliandra (Calliandra calothyrsus) as a forage in the different defoliation time. Buletin Peternakan. 39(2): 103-108.

AOAC. 2005. Official Methods of Analysis. Association of Official Analytical Chemists. Editor: Horwitz, W. and Latimer G. W., Jr. Published by AOAC International. 18th Edition. USA

Casey, N. 2015. Plant leaves in food preparation and packaging. Utar Agriculture Science Journal. 1(4): 34-39

Cheong, M.W., Tong, K.H., Ong, J.J.M., Liu, S.Q., Curran, P. and Yu, B. 2013. Volatile composition and antioxidant capacity of Arabica coffee. Food Research International. 51(1): 388-396.

Grover, N. and Patni, V., 2013. Phytochemical characterization using various solvent extracts and GC-MS analysis of methanolic extract 
of Woodfordia fruticosa (L) Kurz. Leaves. Int J Pharm Pharm Sci. 5(4): 291-295.

Guo, M., Zhang, T.H., Chen, B.W. and Cheng, L., 2014. Tensile strength analysis of palm leaf sheath fiber with Weibull distribution. Composites Part A: Applied Science and Manufacturing. 62: 45-51.

Haines, T.D., Adlaf, K.J., Pierceall, R.M., Lee, I., Venkitasubramanian, P. and Collison, M.W. 2011. Direct determination of MCPD fatty acid esters and glycidyl fatty acid esters in vegetable oils by LC-TOFMS. Journal of the American Oil Chemists' Society. 88(1): 1-14.

Ibañez, S., Rosa, M., Hilal, M., González, J.A. and Prado, F.E. 2008. Leaves of Citrus aurantifolia exhibit a different sensibility to solar UV-B radiation according to development stage in relation to photosynthetic pigments and UV-B absorbing compounds production. Journal of Photochemistry and Photobiology B: Biology. 90(3): 163169.

Kuo, J.M., Hwang, A., Yeh, D.B., Pan, M.H., Tsai, M.L. and Pan, B.S. 2006. Lipoxygenase from banana leaf: Purification and characterization of an enzyme that catalyzes linoleic acid oxygenation at the 9-position. Journal of agricultural and food chemistry. 54(8): 3151-3156.

Koten, B.B., Soetrisno, R.D., Ngadiyono, N. and Soewignyo, B. 2013. Penampilan produksi hijauan hasil tumpangsari arbila (phaseolus lunatus) berinokulum rhizobium dan sorgum (sorghum bicolor) pada jarak tanam arbila dan jumlah baris sorgum. Sains Peternakan. 11(1): 26-33.

Maflahah, Iffan. 2012. Desain Kemasan Makanan Tradisional Madura dalam Rangka Pengembangan IKM. Agrointek. 6(2):118-122

Muthulakshmi, A., Jothibai, M. R., and Mohan, V. R. 2012. GC-MS analysis of bioactive components of Feronia elephantum Correa (Rutaceae). Journal of Applied Pharmaceutical Science. 2(2): 69-74.

Natadjaja, L. and Yuwono, E. C. 2017. Kearifan Lokal Kemasan Panganan Tradisional. Chapter 2., pp.7

Nayeem, N. and Karvekar, M.D. 2010. Comparative phytochemical and pharmacological screening of the methanolic extracts of the frontal and mature leaves of Tectona grandis. International Journal of Pharma and Bio Sciences. 1(3): 5.

Noviadji, B.R. 2014. Desain kemasan tradisional dalam konteks kekinian.
Jurnal Fakultas Desain. 1(1): 10-21.

Salisbury, F.B. and Ross, C.W. 1995. Fisiologi Tumbuhan Jilid 1. ITB Bandung.

Sec, P., Garaiova, M., Gajdos, P., Certik, M., Griac, P., Hapala, I. and Holic, R. 2015. Baker's yeast deficient in storage lipid synthesis uses cis-vaccenic acid to reduce unsaturated fatty acid toxicity. Lipids. 50(7): 621-630.

Shibahara, A., Yamamoto, K., Nakayama, T. and Kajimoto, G. 1986. cisVaccenic acid in mango pulp lipids. Lipids: 21(6): 388-394. https:// doi.org/10.1007/BF02534933

Shibahara, A., Yamamoto, K., Nakayama, T. and Kajimoto, G. 1987. cisVaccenic acid in pulp lipids of commonly available fruits. Journal of the American Oil Chemists' Society. 64(3): 397-401. https://doi. org/10.1007/BF02549303

Socaci, S.A., Tofană, M., Socaciu, C. and Semeniuc, C., 2009. Optimization of HS/GC-MS method for the determination of volatile compounds from indigenous rosemary. Journal of Agroalimentary Processes and Technologies. 15: 45-49.

Tsai, M. H., \& Li, L. T. 2021. Leaf color as a morpho-physiological index for screening heat tolerance and improved water use efficiency in rabbiteye blueberry (Vaccinium virgatum Aiton). Scientia Horticulturae 278 (2021) 109864

White, J.W. and Montes-R, C. 2005. Variation in parameters related to leaf thickness in common bean (Phaseolus vulgaris L.). Field Crops Research. 91(1): 7-21.

Zhang, M.P., Zhang, C.J., Yu, G.H., Jiang, Y.Z., Strasser, R.J., Yuan, Z.Y., Yang, X.S. and Chen, G.X. 2010. Changes in chloroplast ultrastructure, fatty acid components of thylakoid membrane and chlorophyll a fluorescence transient in flag leaves of a super-highyield hybrid rice and its parents during the reproductive stage. Journal of plant physiology. 167(4): 277-285. 